\title{
Dysfunction of Foreign Worker Employment Regulation to Prevent Xenophobia
}

\author{
Widiatama $^{1}$, I Gusti Ayu Ketut Rachmi Handayani², Lego Karjoko ${ }^{3}$ \\ ${ }^{1.2 .3}$ Faculty of Law, Universitas Sebelas Maret \\ Surakarta, Indonesia \\ widiatama@student.uns.ac.id
}

\begin{abstract}
This research studies the Presidential Regulation Number 20 of 2018 about Foreign Worker Employment. There is still a conflict of norm between the Presidential Regulation Number 20 of 2018 about Foreign Worker Employment and the Law Number 13 of 2003 about Manpower. The research method employed was normative one that was prescriptive in nature with statute approach. Technique of collecting law material used was library study, while technique of analyzing data used was deductive method. To find out and to analyze the problem Pancasila justice and critical legal study theories were used. This research concluded that there is disharmony between the Presidential Regulation Number 20 of 2018 about Foreign Worker Employment and the higher regulation, the Law Number 13 of 2003 about Manpower. If the entry of foreign workers is not treated wisely, xenophobia phenomenon will potentially occur in the future in Indonesia.
\end{abstract}

Keywords-Manpower, Foreign workers, Xenophobia.

\section{INTRODUCTION}

Constitutional state originates from the Rule of Law's ideals. A.V. Dicey and Sir I. Jennings state that "all of state powers originate from law, and law builds on high humanity values that are personal in nature". Law protection for workers is the fulfillment of inherent basic rights protected by constitution as governed in Article 27 clause (2) of 1945 Constitution stating that "Every citizen shall have the right to work and to earn a humane livelihood" and Article 33 clause (1) stating that "The economy shall be organized as a common endeavor based upon the principles of the family system".[1]

The protection of workers is intended to ensure the basic rights of workers and the equality and equal treatment without discrimination to achieve the workers and their families' welfare by remaining to pay attention the development and progress of business world and the employers' interest. Legislation related to the workers is written in Law Number 13 of 2003 about Manpower and Implementation Regulation of Legislation in Manpower field.[2]

President Joko Widodo has signed Presidential Regulation (Perpres) Number 20 of 2018 about Foreign Worker Employment. Presidential Regulation is one of policies made by President Joko Widodo in the attempt of welcoming "Industrial Revolution 4.0" and supporting the acceleration of infrastructural development in Indonesia. Overall, the regulation contains facilities provided to the foreigners who work in Indonesia.[3]

The facilities mentioned in the Perpres, according to President Joko Widodo, are an attempt of attract foreign investors to invest in Indonesia. The entry of foreign investment into Indonesia is expected to activate Indonesian economy, in order to improve Indonesia's competitiveness compared with other states. The entry of foreign capital used to activate Indonesian economy is expected to absorb Indonesian workers in order to achieve wellbeing. The number of potential workers increasing continuously is expected to be absorbed by the existing infrastructural development.[4]

However, in reality the entry of foreign investment into Indonesia is also followed with the entry of foreign workers into this state. The Director General of Workers Building and Placement and Job Opportunity Expansion of Manpower Ministry, Maruli Apul Hasoloan, explained that there have been 95,335 foreign workers in late 2018 . This figure increases by $10.88 \%$ compared with that it in $2017,85,974$ workers. It is a substantial figure compared with the number of foreign workers coming into Indonesia in the period of 2011-2014. In that period, the number of foreign workers coming into Indonesia decreased by $8.95 \%$ annually on average.[5]

Unemployment rate in Indonesia increases from year to year. In 2017, there is an increase in unemployment rate by $0.14 \%$ or 10,000 persons, from 7.03 millions in August 2016 to 7.04 millions on August 2017. The massive entry of foreign workers into Indonesia will make the people restless. People who have not gotten job yet will feel marginalized with the entry of foreign workers into Indonesia. It, of course, will gradually result in envy among Indonesian workers and trigger negative sentiment to the entry of foreign workers into Indonesia.[6]

Such condition has occurred widely in North American and European Union states. This is called "Xenophobic" violence in South Africa. A series of attacks against immigrants committed by South Africans for a month in 2015 has taken at least 5 immigrant life tolls and made about 5,000 persons leaving from their residence. Military has been sent down to pacify the situation getting hotter due to the action that has spread to Johannesburg capital.[7]

The massive entry of foreign workers into Indonesia recently should be treated wisely, in order to prevent it from generating xenophobic sentiment. The ratification of Presidential Regulation Number 20 of 2018 about Foreign Worker Employment will have an impact on 
Indonesian workers. Considering the background and departing from the problem identification aforementioned, the basic problem to be studied further is how the regulation of foreign worker employment is in Indonesia that can reflect justice value.[8]

\section{RESEARCH METHOD}

This study was a doctrinal legal research that is prescriptive in nature and discusses doctrines and principles of legal science. This research is used to study legal substance and structure, to analyze synchronization and systematization of legal regulation providing legal map and direction either vertically or horizontally.[9] The approach used in this research was (statute approach). Primary law materials used in this research were 1945 Constitution, Law Number 13 of 2003 about Manpower, Presidential Regulation Number 20 of 2018 about Foreign Worker Employment. Secondary law materials used were books, journal, and papers substantively relevant to the theme and problem of research.[10]

\section{FINDINGS AND DISCUSSION}

\section{Legal Analysis on the Presidential Regulation Number 20 of 2018 about Foreign Worker Employment}

To support national economy and to expand job opportunity through improving investment, the government considers the importance of reforming the regulation about the license of foreign worker employment. For that reason, President Joko Widodo has signed Presidential Regulation (Perpres) Number 20 of 2018 about Foreign Worker Employment on March 26, 2018. This regulation mentions that the employment of foreign workers is conducted by the employers for foreign workers in work relation for certain position and time, by considering the condition of domestic labor market.[11]

Each of employers for foreign workers, according to this Regulation, should obligatorily prioritize the employment of Indonesian workers in all positions available. In the case of position aforementioned has not been able to be occupied by Indonesian workers, it can be occupied by the foreign ones. "Foreign workers are prohibited from occupying the position of personnel management and/or certain position specified by the Minister", as specified in Article 5 clause (1) of Presidential Regulation.[12]

This Presidential Regulation confirms that the employers for foreign workers in certain sector can employ the foreign workers who are employed by other employers on the same position. The occupation period is up to the end of foreign workers' occupation period corresponding to the work contract. Position type, sector, and mechanism of foreign worker employment aforementioned, according to this Presidential Regulation, are governed in the Minister's Regulation.[13]

This Presidential Regulation confirms that each of Employers employing foreign workers should have Foreign Worker Employment Plan (Rencana Penggunaan Tenaga Kerja Asing or RPTKA) legalized by Minister or designated official, and containing: a. reason of foreign worker employment; b. function and/or position foreign workers in the company's organizational structure; c. Foreign worker employment period; and d. designation of Indonesian workers as the assistant of foreign workers employed.[14]

The provision is effective unless the foreigner workers employed are: a. share holder constituting the member of board of directors or board of commissioners in the employers; b. diplomatic and consular employees in the foreign country representative; or c. foreign workers in the type of job needed by the government," as mentioned in Article 10 clause (1) of Presidential Regulation. For emergency and urgent job, according to this Presidential Regulation, Employers can employ foreign workers by filing the application for the legalization of RPTKA to the Minister or the designated official no later than 2 (two) weekdays after the foreign workers are employed. Furthermore, the legalization of RPTKA will be given no later than a weekday following the acceptance of application completely.[15]

This Presidential Regulation confirms that Employers which will employ foreign workers inform the data of potential foreign workers to the Minister or the designated official, including: a. name, sex, place and date of birth; $b$. nationality, passport number, passport period, and place of passport publication; c. name, function, and working period; d. employers' guarantee statement; and e. educational certificate and job recommendation letter or competency certificate corresponding to the requirement of position to be occupied by the foreign workers. "Minister or designated official notifies the acceptance of data of potential foreign workers aforementioned to the employers no later than 2 (two) weekdays forwarded to the Directorate General of Immigration", as mentioned in Article 14 clause (3) of the Presidential Regulation.[16]

The employers of foreign workers, according to this Presidential Regulation, should obligatorily pay compensation fund for the employment of foreign workers following the acceptance of notification and the payment is done through the bank designated by Minister, constituting Non-Tax State Revenue. This payment of compensation fund for the employment of foreign worker and obligation of having RPTKA is not compulsory to governmental institution, foreign country representative, and international agency employing foreign workers.[17]

This Presidential Regulation confirms that every foreigners working in Indonesia should have Admission (Visa Tinggal Terbatas or VITA) for working applied by the Employers of Foreign Workers or the Foreign Workers to the Minister dealing with governmental affairs in legal and human right area or the official designated, by attaching notification and receipt. "The application for admission aforementioned can be the application for Temporary Stay Permit (Permohonan Izin Tinggal Sementara or Itas)," as mentioned in Article 20 clause (1) of the Presidential Regulation.[18]

In the case of application for Temporary Stay Permit and for Admission all at once, according to this Presidential Regulation, the process of applying for Temporary Stay permit is implemented by Republic of 
Indonesia's Representative abroad, constituting the extension of Directorate General of Immigration.

The elaboration above reveals the analysis on the Presidential Regulation Number 20 of 2018 about the Employment of Foreign Workers. From the elaboration above, it can be seen that in President Joko Widodo's government, the employment of foreign workers is facilitated through administration requirement, and the period of requirement preparation. It will likely affect positively the development in Indonesia, but the easier requirement and the shorter period of administration preparation putatively provides lead to the error in the process of selecting foreign workers so that unqualified workers can enter into and work in Indonesia, perhaps due to limited time.[19]

\section{The Regulation of Foreign Workers to Achieve Justice for Indonesian Workers}

Justice perspective in national law to Indonesia refers to the state's foundation, Pancasila, the fifth principle of which states "Social Justice for all Indonesians". The problem currently is what does the word "just" means according to the national law concept originating from Pancasila values? Kahar Masyhur, in a book entitled Building Moral and Character, provides four definitions of just: (1) being just is putting something on its place, (2) being just is receiving the right exactly, not more and giving right to others exactly, not less, (3) being just is giving everyone entitled his right completely, neither more nor less, between the fellows entitled in the equal condition, and (4) being just is to sentence the criminals or those breaking the law according to the guilt and infringement they have done.[20]

The second principle of Pancasila as the national legal source of Indonesians essentially instructs us to establish harmonious relationship between human individually and other individual groups, thereby creating just and civilized relation. This just and civilized relation can be equated with light and fire; if the fire gets bigger, the light will be brighter. So, the higher the civilization, the more wellestablished is the justice. Furthermore, in relation to "Social Justice", justice should be associated with the context of society. Social justice, according to Purnadi and Soerjono, is defined as: (1) restoring the deprived rights to those entitled, (2) eradicating mistreatment, fear and rape committed by employer and ruler, (3) realizing the equality before the law for each of individuals, employers, and the rich ones obtaining wealth unfairly.[21]

National law governs justice to everyone and all parties; therefore, justice in national legal perspective is the justice harmonizes justices that are common in nature among individual justices. Social justice emphasizes on the balance between individual rights and common obligation existing in group or society. Gunarto says that Indonesians actually have had reference or guideline about how to implement social justice, particularly the Social Justice principle to Indonesians. In his opinion, the word "justice" in the fifth principle of Pancasila has sharper economic meaning than "justice" in the second principle of Pancasila that is spiritual-nuanced.[22]

According to the justice as mentioned in Pancasila, the entry of foreign workers can be treated through two roles: the role taken by government and the one taken by people. The role of government as the organizer of state is to develop regulation or to give permit (bestuur), to prevent something likely occurring (politie), and to take legal attempt to cope with it (rechtspraak). The role of society (people) is to be tolerant to foreign workers as long as their entry has been compatible to the regulation existing and developed by the government. Thus, the idealized justice will be brought into reality.[23]

\section{Critical Legal Study theory (a study on the distrust in rule).}

In drafting the law, legislative body is affected by two interests: power and market (economic) relations. Therefore "biased" legislative language is created deliberately in the legislation in order to be interpreted based on the ruler's interest. Presidential Regulation (Perpres) Number 20 of 2018 about the employment of foreign workers implies the government's partiality to Foreign Workers. The spotlight focuses, of course, on the entry of foreign workers coming in great number: 21,300 workers from China, 1,700 workers from Singapore, and 12,500 workers from Japan.[1]

Indonesian Science Institution (Lembaga Ilmu Pengetahuan Indonesia or LIPI) records a dramatic increase in China's investment in Indonesia. In 2016, China was on the $3^{\text {rd }}$ position as the biggest investor, with USD 2.665 millions investment value or $9 \%$ of total investment in Indonesia. It increases by USD 628 millions or $2 \%$ of total foreign investment in Indonesia.[16]

Since 2016, China has invested substantial capital in Indonesia, with USD 2.665 millions or $9 \%$ of total Investment in Indonesia. An example of China's investment in Indonesia can be seen in the construction of Labuhan Angin Electric Steam Power Plant (PLTU Labuhan Angin) in Labuhan Angin Village, Sibolga City, North Sumatera in 2003. The project's fund source comes from China's loan fund of USD 208.7 millions. The execution of project, from design and construction works, to material and turbine procurement, is done by China's State-Owned Enterprise. In this strategic project, the Chinese company brings Chinese workers to Sibolga, including engineers and blue collar workers, to work on the power plant project.[3]

Actually these foreign workers coming from foreign countries can be controlled easily using Articles 42-49 of Law Number 13 of 2003 about Manpower. However, it becomes difficult in the enactment of Presidential Regulation (Perpres) Number 20 of 2018 about the Employment of Foreign Workers, particularly Article 4 clause (2) stating that "In the case of position as mentioned in clause (1) not occupied by Indonesian workers yet, it can be occupied by foreign workers". From this, we can see the government's partiality to foreign workers. This Perpres as if legalizes the employment of foreign workers in all lines of occupation.[2] 


\section{CONCLUSION}

The enactment of Presidential Regulation Number 20 of 2018 about the employment of foreign workers gives the Indonesian workers the difficult position. In this regulation, the employment of foreign workers is facilitated from administration requirement and requirement preparation period. It will likely affect the development positively in Indonesia, but the easier requirement and the shorter period of administration preparation lead to the error in the process of selecting foreign workers so that unqualified workers can enter into and work in Indonesia, perhaps due to limited time. Government should empower Indonesian workers more, because many of them have not been absorbed yet by the job opportunity existing in Indonesia. Even when the type of occupation still can be done by Indonesian workers, it is unnecessary to employ foreign workers. It is an attempt of making Indonesian people prosperous and a manifestation of our love to Indonesia. This Presidential Regulation is an example of regulation impartial to Indonesians' interest and not protecting Indonesian workers. Government that should protect its citizens instead makes them in trouble position in their own state, with the entry of foreign workers. If the entry of foreign workers into Indonesia is not controlled immediately, it perhaps will lead to xenophobic sentiment, just like the one occurring in South Africa.

\section{REFERENCES}

[1] R. Danendra, I. G. Ayu, K. Rachmi, and A. K. Jaelani, "Legal Protection of Non Wage Workers Rights After Omnibus Law," Jurisprudentie, vol. 8, no. 13, pp. 85-99, 2021.

[2] E. Suhartini, Hartiwiningsih, I. G. A. K. R. Handayani, and M. Roestamy, "Legal politics and policy setting of wage systems for creating social justice of workers," $J$. Leg. Ethical Regul. Issues, vol. 22, no. 6, pp. 1-7, 2019.

[3] N. Zubaidi, R. G. Pratama, and S. Al-Fatih, "Legal Perspective on Effectiveness of Pre-Work Cards for Indonesian People," Bestuur, vol. 8, no. 1, p. 9, 2020.

[4] E. S. Devadason and C. W. Meng, "Policies and Laws Regulating Migrant Workers in Malaysia: A Critical Appraisal," J. Contemp. Asia, vol. 44, no. 1, pp. 19-35, 2014.

[5] L. E. Susanti, "Economic Law Creation Beautiful Global Indonesia," Bestuur, vol. 7, no. 1, p. 47, 2020.

[6] H. A. Lee, "Affirmative Action in Malaysia: Education and Employment Outcomes since the 1990s," J. Contemp. Asia, vol. 42, no. 2, pp. 230-254, 2012.

[7] U. K. Mishra and A. Negi, "Transgender and the Right to Employment in India: Analysing the Trajectories of Discrimination," Bestuur, vol. 9, no. 1, pp. 34-43, 2021.

[8] E. S. Devadason, "Foreign Labour Policy and Employment in Manufacturing: The Case of Malaysia," $J$. Contemp. Asia, vol. 51, no. 3, pp. 398-418, 2021.
[9] L. Karjoko, Z. N. Rosidah, and I. G. A. K. R. Handayani, "Refleksi Paradigma Ilmu Pengetahuan Bagi Pembangunan Hukum Pengadaan Tanah Lego," Bestuur, vol. 7, no. 2, pp. 1-14, 2019.

[10] Z. N. Rosidah, "Coherence of the Rules of Sharia Against Pancasila," Bestuur, vol. 8, no. 1, p. 40, 2020.

[11] L. C. Lintang, Adriano Martufi, and J.W. Ouwerker, "The Alternative Concepts of Blasphemy Law in Indonesia: Legal Comparison with Ireland and Canada," Bestuur, vol. 8, no. 2, pp. 121-128, 2020.

[12] M. Pungky and H. Wijaya, "Legislation Impediments in Reorganising Government Bodies in Indonesia," Bestuur, vol. 9, no. 1, pp. 1-16, 2021.

[13] Saidah Fasihah Binti Che Yussoff and R. Nordin, "Freedom of Expression in Malaysia: Compatibility with the International Human Rights Standard Saidah," Bestuur, vol. 9, no. 1, pp. 44-59, 2021.

[14] H. J. Noor, K. Afkar, H. Glaser, and U. G. Mada, "Application of Sanctions Against State Administrative Officials Failing to Implement Administrative Court Decisions," Bestuur, vol. 9, no. 1, pp. 73-93, 2021.

[15] S. R. Novikasari, D. Q. Ly, and K. Gershaneck, "Taxing Micro, Small and Medium Enterprises in Yogyakarta: Regulation and Compliance," Bestuur, vol. 9, no. 1, 2021.

[16] N. P. Hidayah, "The Implementation of Labor Development Principles According to Job Creation Law as a Reason to Protect Wages Rights," Bestuur, vol. 8, no. 2, pp. 121-128, 2020.

[17] W. B. Putri et al., "Medicolegal Perspective on PhysicianInduced Demand Issue," Bestuur, vol. 9, no. 1, pp. 106124, 2021.

[18] A. Ma'ruf, “Application of Timber Legality Verification System (SVLK) Policy as Ecolabel Implementation in the Indonesian Timber Industry," J. Hum. Rights, Cult. Leg. Syst., vol. 1, no. 2, pp. 92-99, 2021.

[19] S. D. Baranyanan, "Simplification of Law Regulations in Copyright Criminal Act Settlement," J. Hum. Rights, Cult. Leg. Syst., vol. 1, no. 2, pp. 80-91, 2021.

[20] I. Iswantoro, "Strategy and Management of Dispute Resolution, Land Conflicts at the Land Office of Sleman Regency," J. Hum. Rights, Cult. Leg. Syst., vol. 1, no. 1, pp. 1-17, 2021.

[21] A. Ma, "Legal Aspects of Environment in Indonesia : an Efforts to Prevent Environmental Damage and Pollution," J. Hum. Rights, Cult. Leg. Syst., vol. 1, no. 1, pp. 18-30, 2021.

[22] Syahlan, "Effective and Efficient Synchronization in Harmonization of Regulations Indonesia," J. Hum. Rights, Cult. Leg. Syst., vol. 1, no. 1, pp. 54-70, 2021.

[23] R. Res, "Implementation of Parate Executie Object of Liability Juridical Overview of Mortgage," J. Hum. Rights, Cult. Leg. Syst., vol. 1, no. 1, pp. 42-53, 2021. 